\title{
HOXC10 is overexpressed in breast cancer and transcriptionally regulated by estrogen via involvement of histone methylases MLL3 and MLL4
}

\author{
Khairul I Ansari, Imran Hussain, Sahba Kasiri and Subhrangsu S Mandal \\ Department of Chemistry and Biochemistry, The University of Texas at Arlington, Arlington, TX 76019, USA \\ (Correspondence should be addressed to S S Mandal; Email: smandal@uta.edu)
}

\begin{abstract}
HOXC10 is a critical player in the development of spinal cord, formation of neurons, and associated with human leukemia. We found that $\mathrm{HOXC10}$ is overexpressed in breast cancer and transcriptionally regulated by estrogen (17 $\beta$-estradiol, $\mathrm{E}_{2}$ ). The HOXC10 promoter contains several estrogen response elements (ERE1-7, half-sites). A luciferase-based reporter assay showed that ERE1 and ERE6 of HOXC10 promoter are $E_{2}$ responsive. ER $\alpha$ and ER $\beta$ play critical roles in $\mathrm{E}_{2}$-mediated activation of $H O X C 10$. Knockdown of $\mathrm{ER} \alpha$ and $\mathrm{ER} \beta$ downregulated $\mathrm{E}_{2}$-induced $H O X C 10$ expression. ER $\alpha$ and ER $\beta$ bind to ERE1 and ERE6 regions in an $E_{2}$-dependent manner. Additionally, knockdown of histone methylases MLL3 and MLL4 (but not MLL1 and MLL2) diminished $\mathrm{E}_{2}$-induced expression of HOXC10. MLL3 and MLL4 were bound to the ERE1 and ERE6 regions of $H O X C 10$ promoter in an $\mathrm{E}_{2}$-dependent manner. Overall, we demonstrated that $\mathrm{HOXC10}$ is overexpressed in breast cancer, and it is an $E_{2}$-responsive gene. Histone methylases MLL3 and MLL4, along with ERs, regulate $\mathrm{HOXC10}$ gene expression in the presence of $\mathrm{E}_{2}$.
\end{abstract}

Journal of Molecular Endocrinology (2012) 48, 61-75

\section{Introduction}

Homeobox $(H O X)$ genes are evolutionarily conserved genes that play critical roles in cell differentiation and embryonic development (Lawrence et al. 1996, Lappin et al. 2006). HOX genes are also essential in differentiation of adult tissues (Daftary \& Taylor 2006). In general, HOX genes encode transcription factors that bind to promoters of various target genes through their homeodomain controlling their expression. HOX genes are associated in specifying primary and secondary body axis of embryos in animals (Gehring 1993, Huang et al. 2007). In humans, there are 39 HOX genes arranged in four clusters (HOX $A-D)$ located in four different chromosomes. Based on sequence similarities and location within the cluster, $H O X$ genes are classified into 13 paralogous groups (Alexander et al. 2009). Hox genes located in the 3 -end of the cluster are expressed in the anterior (head) region of the embryo, while genes located in the $5^{\prime}$-end of the cluster are expressed in the exterior (tail) region. The colinearity of expression boundaries and position is highly conserved from flies to mammals (Alexander et al. 2009). HOX proteins are also associated with oncogenic transformation of hematopoietic cells (van Oostveen et al. 1999, Fu et al. 2003).

Hoxa10, Hoxc10, and Hoxd10 are three paralogous genes that are expressed in the lumbar spinal cord and have distinct expression patterns (Choe et al. 2006).
Inactivation of these genes either in combination or alone affects motor neuron patterning (Choe et al. 2006). Hoxc10 and paralogous genes have also been implicated in endometrial differentiation (Akbas et al. 2004). Gene expression analysis in preinvasive and invasive cervical cancer cells demonstrated that HOXC10 expression is elevated in invasive cells and linked with the invasiveness of human papillomavirusimmortalized keratinocytes and cervical cancer cells (Lopez et al. 2006, Zhai et al. 2007). Knockdown of HOXC10 expression reduces the invasiveness of cervical cancer cells, indicating its key role in cervical cancer progression (Zhai et al. 2007). Although HOXC10 is a critical gene in the spinal cord and neuronal development and in cervical cancer progression, the mechanism of HOXC1O gene expression still remains elusive. Recently, several hormones (such as estrogen, progesterone, and retinoic acids) have been shown to regulate different $H O X$ genes and allow generation of structural and functional diversity in embryonic and adult tissues (Ma et al. 1998, Lane et al. 2004, Daftary \& Taylor 2006, Huang et al. 2007, Taylor 2008).

Mixed lineage leukemias (MLLs) are well known as master regulators of HOX genes (Hess 2004, Guenther et al. 2005). MLLs are evolutionarily conserved family of histone methyltransferases (HMTs) that specifically methylate histone $\mathrm{H} 3$ at lysine 4 (H3K4) and regulate gene activation (Hanson et al. 1999, Yokoyama et al. 2004, Bannister \& Kouzarides 2005, Glaser et al. 2006,

DOI: 10.1530/JME-11-0078 Online version via http://www.endocrinology-journals.org 
Sims \& Reinberg 2006, Bhaumik et al. 2007, Issaeva et al. 2007, Agger et al. 2008, Ansari et al. 2009a,b,c). MLLs are also associated with various oncogenic transformations including myeloid and lymphoid leukemia (So \& Cleary 2004, Meyer et al. 2006). In humans, there are several proteins of MLL family such as MLL1, MLL2, MLL3, MLL4, etc. They exist as distinct multiprotein complexes inside cells with several common subunits including ASH2, WDR5, RBBP5, CGBP, and DPY30 (Lee \& Skalnik 2005, Crawford \& Hess 2006, Dou et al. 2006, Ansari et al. 2008, Trievel \& Shilatifard 2009). Recently, we have demonstrated that MLL1 and H3K4 trimethylation have distinct dynamics during cell cycle progression and play critical roles in gene activation (Ansari et al. 2008, 2009a,b,c, Mishra et al. 2009). Knockdown of MLL1 results in cell cycle arrest at G2/M phase, suggesting its critical role in cell cycle progression (Takeda et al. 2006, Ansari et al. $2009 a, b, c)$. In particular relevance to our study, sequence analysis demonstrated that MLLs (MLL1-4) possess one or more LXXLL domains (also called NR-box) (Dreijerink et al. 2006, Mo et al. 2006, Ansari et al. 2009a,b,c, Lee et al. 2009). Proteins containing NR-boxes are well known to interact with nuclear hormone receptors and play key roles in hormone signaling (Nilsson et al. 2001, Lee et al. 2006, 2009). Indeed, MLL2 interacts with estrogen receptors (ERs) and regulates estrogen-dependent activation of cathepsin D (Mo et al. 2006). Similarly, MLL3 and MLL4 play essential roles in nuclear receptor-mediated gene activation including liver X-receptor (LXR; Lee et al. 2006, 2009).

Herein, in an effort to understand the mechanism of HOX gene regulation by MLLs, we found that HOXC1O is overexpressed in breast cancer and is transcriptionally regulated by estrogen. Mechanistic studies demonstrated that histone methylases MLL3 and MLL4, in coordination with ERs, play critical roles in estrogenmediated activation of HOXC1O.

\section{Materials and methods}

\section{Cell culture, estrogen treatment, and antisense experiment}

Human choriocarcinoma placenta cells (JAR), human adenocarcinoma mammary (MCF7), ER-negative human adenocarcinoma mammary (MDA-MB-231), ductal carcinoma mammary (T47D), hepatocellular carcinoma (HEPG2), cervical cancer (HeLa), colorectal adenocarcinoma (SW480), chronic myelogenous leukemia (K562), bronchoalveolar carcinoma (H358), normal breast epithelial (MCF10), normal lung fibroblast (HFL1), and normal placenta (Hs 798.Pl) cells were obtained from ATCC (Manassas, VA, USA) and grown in Phenol Red-free DMEM-F-12 (or RPMI as needed, Sigma), supplemented with $10 \%$ charcoalstripped fetal bovine serum, $2 \mathrm{mM}$ L-glutamine, and penicillin/streptomycin (100 units and $0 \cdot 1 \mathrm{mg} / \mathrm{ml}$ ). For estrogen treatment experiments, cells were grown in $10 \mathrm{ml}$ culture dish to $70 \%$ confluency and treated with different concentrations $(0-1000 \mathrm{nM})$ of estrogen (17 $\beta$-estradiol, $\left.\mathrm{E}_{2}\right)$ in the absence or presence of tamoxifen and incubated for $8 \mathrm{~h}$ (or varying time points for temporal studies) and then harvested for RNA and proteins extraction.

For the antisense experiments, JAR cells were grown up to $60 \%$ confluency in $60 \mathrm{~mm}$ culture plate and transfected with varying amounts $(3-9 \mu \mathrm{g})$ of different antisenses in FBS-free media as described by us previously (Ansari et al. 2008, 2009a,b,c; Table 1). In brief, a cocktail of antisense and ifect transfection reagents (MoleculA) was made in $300 \mu$ culture media (without supplements) as instructed by the manufacturer. Cells were washed twice with culture media (without supplements) and $1.7 \mathrm{ml}$ media (without supplements) was added to the plate. The antisensetransfection reagent cocktail was applied to the cells, incubated for $7 \mathrm{~h}$ before addition of $2 \mathrm{ml}$ culture media with all supplements and 20\% charcoal-stripped FBS. Cells were then incubated for an additional $48 \mathrm{~h}$.

\section{Preparation of RNA and protein extract}

The RNA and proteins were extracted using similar procedure as described by us previously (Ansari et al. 2008, 2009a,b,c). In brief, the cell pellets were resuspended in diethyl pyrocarbonate (DEPC)-treated buffer A (20 mM Tris-HCl, pH 7.9; $1.5 \mathrm{mM} \mathrm{MgCl}_{2}$; $10 \mathrm{mM} \mathrm{KCl}$ and $0.5 \mathrm{mM}$ dithiothreitol (DTT); and $0.2 \mathrm{mM}$ phenylmethylsulphonyl fluoride), incubated on ice for $10 \mathrm{~min}$, and centrifuged at $3500 \mathrm{~g}$ for $5 \mathrm{~min}$. The supernatant containing the cytoplasmic extracts was subjected to phenol-chloroform extraction followed by $\mathrm{LiCl}$ precipitation of cytoplasmic mRNA by incubating for $1 \mathrm{~h}$ at $-80^{\circ} \mathrm{C}$. The RNA was washed with DEPC-treated $70 \% \mathrm{EtOH}$, air dried, and resuspended in DEPC-treated water.

\section{Reverse transcription-PCR and western blotting}

Reverse transcription (RT) reactions were performed in a total volume of $25 \mu \mathrm{l}$ containing $500 \mathrm{ng}$ RNA, $2 \cdot 4 \mu \mathrm{M}$ oligo-dT (Promega), 100 units MMLV reverse transcriptase, $1 \times$ first-strand buffer (Promega), $100 \mu \mathrm{M}$ each of dATP, dGTP, dCTP, and dTTP (Invitrogen), 1 mM DTT, and 20 units RNaseOut (Invitrogen). The cDNA was diluted to $100 \mu \mathrm{l}$. PCR was performed in a $10 \mu \mathrm{l}$ reaction volume containing $5 \mu \mathrm{l}$ diluted cDNA and gene-specific primer pairs (Table 1). For western blot analysis, an equivalent amount of cell protein extracts $(25 \mu \mathrm{g})$ was 
Table 1 Primers used for RT-PCR and ChIP experiments

Primers

(A) PCR primer GAPDH HOXC10-ORF

MLL1

MLL2

MLL3

MLL4

HOXC10-ERE1

HOXC10-ERE2

HOXC10-ERE3

HOXC10-ERE4

HOXC10-ERE5

HOXC10-ERE6

HOXC10-ERE7

HOXC10-non-ERE

ERE1-pGL3

ERE2/3-pGL3

ERE4/5-pGL3

ERE6-pGL3

ERE7-pGL3

Non-ERE-pGL3

(B) Antisense oligonucleotide

$\mathrm{ER} \alpha$ antisense

ER $\beta$ antisense

MLL1 antisense

MLL2 antisense

MLL3 antisense

MLL4 antisense

Scramble antisense
Forward primer $\left(5^{\prime}-3^{\prime}\right)$

CAATGACCCCTTCATTGACC

ACCACAGGAAATTGGCTGAC

GAGGACCCCGGATTAAACAT

GTGCAGCAGAAGATGGTGAA

AAGCAAACGGACTCAGAGGA

GTCTATGCGCAGTGGAGACA

ATGGCGCTGTTACTCCACTC

TGACCCCCTCCCTGGCCCA

TGGCTTCCTCTTTCCCCTAC

CTGAGATGGTGACCCAGGAG

CGCAGGTTCCCTCTTTCTTT

CGTGCGCTCTGTAAAGGAC

CAAGTCTGGGGCCTAAACAG

TCTTGTGAGGAGGTGGGAGT

CCCTTCTCCCCAGGAGTTAC ${ }^{a}$

TGGCTTCCTCTTTCCCCTAC ${ }^{a}$

CGCAGGTTCCCTCTTTCTTT ${ }^{a}$

CCTAGGCTCTGTCCAAGGAA ${ }^{a}$

TCAAACTGGTGGGGAAAGAC ${ }^{a}$

GAGAAACCAGGGTGCTTCTG ${ }^{a}$

CATGGTCATGGTCAG $^{\mathrm{b}}$
GAATGTCATAGCTGA $^{\mathrm{b}}$
TGCCAGTCGTTCCTCTCCAC $^{\mathrm{b}}$
ACTCTGCCACTTCCCGCTCA $^{\mathrm{b}}$
CCATCTGTTCCTTCCACTCCC $^{\mathrm{b}}$
CCTTCTCTTCTCCCTCCTTGT $^{\mathrm{b}}$
CGTTTGTCCCTCCAGCATCT $^{\mathrm{b}}$

Reverse primer $\left(5^{\prime}-3^{\prime}\right)$

GACAAGCTTCCCGTTCTCAG

GATCCGATTCTCTCGGTTCA

GGAGCAAGAGGTTCAGCATC

GCACAATGCTGTCAGGAGAA

ACAAGCCATAGGAGGTGGTG

AGTCTGCATCCCCGTATTTG

CCAATGGGATTTGAAAATGG

CTCTCCCGCCTCCTCTTTT

ACTGGGAATCTCCAGCCTCT

AAAGGAGGTTCCGAATGGAC

CCGGTTCTGCTGCTTTACTT

GAGCCTCGGTCAGTTTGGAG

CCGGAAAACTGGAAGGAAAT

CAAGGGAGAGGACAGAGTCG

AGGGGAGGGAGGAAAAAGA ${ }^{a}$ CTTACCTTGGGGATGGGAGT

AAAGGAGGTTCCGAATGGAC CCCCGCTAAAACAGGGAATA GTTTCTAAGGAGGCCCAAGC ${ }^{a}$ TGTGCATACGACCTGACAAA ${ }^{a}$

${ }^{\mathrm{a}}$ Flanked by appropriate restriction sites.

${ }^{\mathrm{b}}$ All phosphorothioate.

electrophoresed through SDS-PAGE (10 and 15\% respectively) and transferred to nitrocellulose membrane. The membrane containing the protein extracts was probed with anti-MLL1 (Bethyl Laboratory, Montgomery, TX, USA), anti-MLL2 (LifeSpan BioSciences Inc., Seattle, WA, USA), anti-MLL3 (Abgent, San Diego, CA, USA), anti-MLL4 (Sigma), anti-ER $\alpha$ (Santa Cruz, Biotechnologies, Santa Cruz, CA, USA), anti-ER $\beta$ (Santa Cruz), and anti- $\beta$-actin (Sigma) antibodies. Western blots were developed using the alkaline phosphatase method.

\section{Immunohistological analysis of breast cancer tissue microarray}

The breast cancer tissue microarray slide containing six different cases (duplicates of each) of breast cancer and their corresponding adjacent normal tissue were purchased from US Biomax, Inc. (Rockville, MD, USA) and subjected to immunohistological staining. For staining, the paraffin-embedded tissue microarray slide was immersed twice in xylene (for $10 \mathrm{~min}$ ) and then sequentially immerged in 100, 95, and $70 \%$ ethanol (5 min each) to deparaffinize the tissue. Antigen retrieval was done by incubating the slide in $0.01 \mathrm{M}$ sodium citrate buffer at $95^{\circ} \mathrm{C}$ for $15 \mathrm{~min}$ following the supplier's instruction. For immunohistological staining, the tissue microarray slide was incubated with $3 \% \mathrm{H}_{2} \mathrm{O}_{2}$ for $15 \mathrm{~min}$, washed with PBS thrice, and then blocked with blocking buffer containing donkey serum. The slide was then incubated with HOXC1O antibody overnight, washed three times in PBS, and then incubated with biotinylated donkey secondary antibody for $1.5 \mathrm{~h}$. The slide was washed thrice with PBS, incubated with avidin-biotin complex (ABC; Vector Laboratories, Burlingame, CA, USA) for $1.5 \mathrm{~h}$, washed twice with PBS, and then washed twice with $0 \cdot 1 \mathrm{M}$ Tris- $\mathrm{HCl}(\mathrm{pH} 7 \cdot 4)$. The slide was incubated with diaminobenzidine (DAB) substrate (Vector Laboratories) for peroxidase labeling. The tissue microarray slide was dehydrated with sequential immersion under 70, 95, and $100 \%$ ethanol and then cleaned by sequentially incubation (1, 5, and $10 \mathrm{~min}$ ) in CitriSolv clearing agent (Fisherbrand, Pittsburgh, PA, USA). Tissue sections were finally mounted with distrene-plasticizer-xylene mounting solution (Sigma), photographed, and examined under a microscope (Nikon Eclipse TE2000-U, Japan).

\section{Dual-luciferase reporter assay}

The HOXC10 full promoter, full promoter with estrogen response element (ERE)-specific mutation, 
and independent ERE regions along with their flanking regions (350-400 bp) were cloned and inserted upstream of the promoter of a firefly luciferase gene in pGL3 promoter vector (Promega) (primers are listed in Table 1). JAR cells $\left(4 \times 10^{5}\right.$ in a six-well plate) were cotransfected with $1500 \mathrm{ng}$ of these ERE containing luciferase reporter construct along with $150 \mathrm{ng}$ of a reporter plasmid containing renilla luciferase (pRLTk; Promega) as an internal transfection control using FuGENE6 transfection reagent. Control transfections were done using pGL3 promoter vector without any ERE insertion or with a luciferase construct-containing segment of HOXC1O promoter containing no ERE (nonspecific control, non-ERE). At $24 \mathrm{~h}$ after transfection, cells were treated with $100 \mathrm{nM} \mathrm{E}_{2}$ and incubated for an additional $8 \mathrm{~h}$ and then subjected to luciferase assay using a dual-luciferase reporter assay kit (Promega) as instructed. Firefly luciferase activities were assayed and normalized to those of renilla luciferase. Each treatment was performed in four replicates and the experiment was repeated at least twice.

\section{Chromatin immunoprecipitation experiment}

Chromatin immunoprecipitation (ChIP) assay was performed using an EZ Chip Chromatin immunoprecipitation kit (Upstate, Billerica, MA, USA) as described previously (Ansari et al. 2008, Mishra et al. 2009). In brief, estrogen-treated and control cells (JAR) were fixed in $4 \%$ formaldehyde, lysed, and sonicated to shear the chromatin. The fragmented chromatins were precleaned with protein-G agarose and subjected to immunoprecipitation with antibodies specific to ER $\alpha$, ER $\beta$, MLL1, MLL2, MLL3, MLL4, H3K4 Tri-Met, and RNAPII (overnight). Immunoprecipitated chromatins were washed and de-proteinized to obtain purified DNA fragments that were PCR amplified using primers specific to different ERE regions of HOXC10 promoter (Table 1).

\section{Real-time PCR analysis}

For gene expression analysis, total RNA was extracted from different cells by using RNAGEM tissue plus the RNA extraction kit (ZyGEM, Hamilton, New Zealand). The RT reactions were performed with $1 \mu \mathrm{g}$ total RNA by using MMLV reverse transcriptase as mentioned above and the cDNA was diluted to $50 \mu \mathrm{l}$ final volume. The cDNA was amplified using SsoFast EvaGreen supermix (Bio-Rad) and primers as described in Table 1, using CFX96 real-time PCR detection system. The results were analyzed using the CFX Manager. The real-time PCR analysis of the ChIP DNA fragments was performed with primer specific to different ERE regions of HOXC1O prompter. Each PCR was performed in triplicate.

\section{Statistical analysis}

Each experiment was done in two to three replicates and then cells were pulled (and treated as one sample), subjected to RNA extraction, RT-PCR, and ChIP analysis, and each experiment was repeated at least thrice $(n=3)$. For luciferase assay, each treatment was performed in four replicates and the experiment was repeated at least twice $(n=2)$. The real-time PCR analysis of such samples was performed in three parallel replicate reactions and each experiment was repeated at least thrice $(n=3)$. Normally distributed data were analyzed by ANOVA and non-normally distributed data were analyzed using Student's $t$-tests (SPSS, Chicago, IL, USA) to determine the level of significance between individual treatments. The treatments were considered significantly different at $P<0 \cdot 05$.

\section{Results}

\section{HOXC10 is overexpressed in breast cancer tissue and placenta choriocarcinoma cells}

In an effort to understand the gene regulatory mechanism of HOXC1O, initially we examined its expression levels in different types of malignant and nonmalignant human cell lines that include T47D (breast cancer), MCF7 (breast cancer), HEPG2 (hepatocellular carcinoma), JAR (placental choriocarcinoma), HeLa (cervical cancer), SW480 (colorectal adenocarcinoma), K562 (chronic myelogenous leukemia), H358 (bronchoalveolar carcinoma), MCF10 (normal breast epithelial), HFL1 (normal lung fibroblast), and Hs798.Pl (normal placenta). RNA was isolated from each cell line, reverse transcribed into cDNA, and analyzed by quantitative real-time PCR (qPCR) for the expression of HOXC10. These analyses showed that HOXC10 expression (mRNA level) was relatively higher in breast cancer cells (MCF7 and T47D), placental choriocarcinoma cells (JAR), and H358 (lung cancer) in comparison to several other cell lines including nonmalignant breast (MCF10) and placental cells (Hs 798.Pl) (Fig. 1A).

As HOX10 expression was higher in breast cancer cells, we further examined its expression in human breast cancer by immunohistological staining of a breast cancer tissue microarray. A tissue microarray containing six cases of breast cancer (in duplicates) along with corresponding adjacent normal tissue was purchased commercially and subjected to DAB staining using HOXC10 antibody. Immunohistological staining showed that the level of HOXC1O expression was distinctly higher (as evidenced by more intense $\mathrm{DAB}$ staining) in each case of breast cancer tissue compared with its corresponding adjacent breast normal tissue (Fig. 1B; quantification is shown in $\mathrm{C}$; a magnified view 


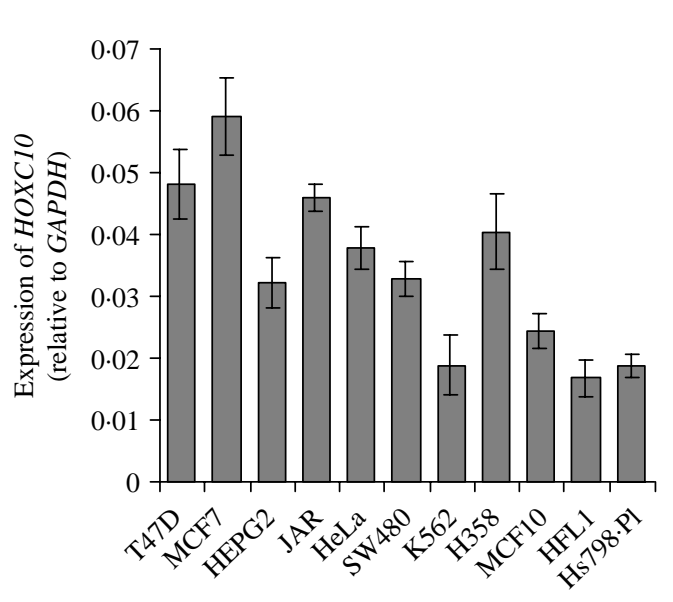

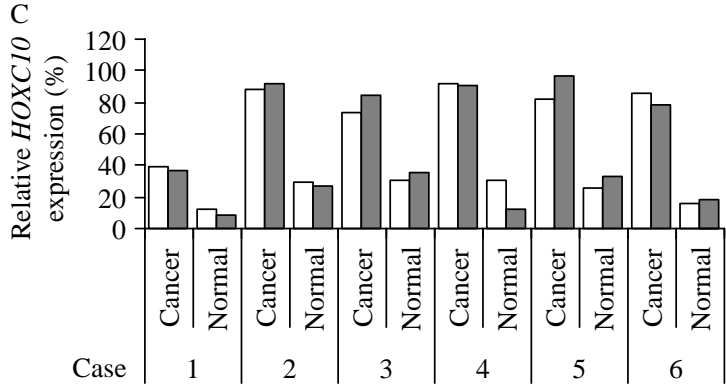

B

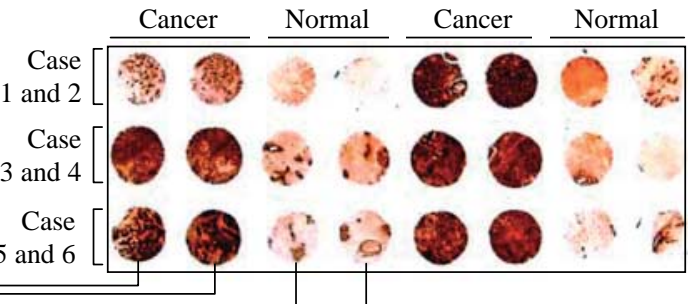

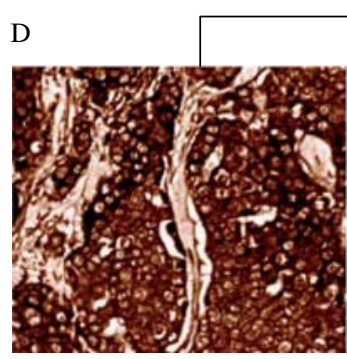

Cancer

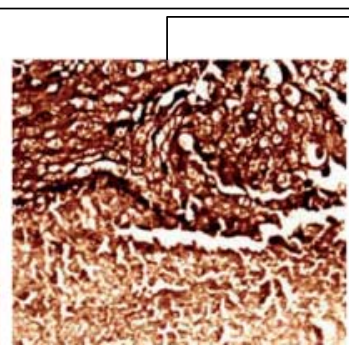

Cancer

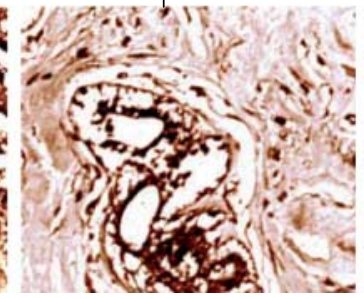

Adjacent normal

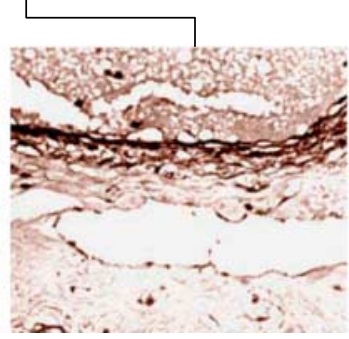

Adjacent normal

Figure 1 Expression of $\mathrm{HOXC10}$ in different malignant and nonmalignant human cell lines and human breast cancer tissue. (A) The total RNA was isolated from T47D (breast cancer), MCF7 (breast cancer), HEPG2 (hepatocellular carcinoma), JAR (choriocarcinoma placenta), HeLa (cervical cancer), SW480 (colorectal adenocarcinoma), K562 (chronic myelogenous leukemia), H358 (bronchoalveolar carcinoma), MCF10 (normal breast epithelial cells), HFL1 (normal lung fibroblast HFL1), and Hs798.PI (normal placenta) cell lines, reverse transcribed to cDNA, and analyzed by real-time PCR using primers specific to HOXC10. GAPDH was used as a loading control. HOXC10 expression relative to GAPDH is plotted. Each experiment was repeated at least thrice $(n=3)$. Bars indicate S.E.M. (B-D) Immunohistological analysis of HOXC10 expression in breast cancer tissue: human breast cancer tissue microarray (six cases of breast cancer along with their matched adjacent normal breast tissue) was obtained from US Biomax and subjected to immunohistological staining (DAB staining) with $\mathrm{HOXC10}$ antibody. The relative quantification of HOXC10 expression within the tissue section is presented in panel $\mathrm{C}$. A magnified view of tissue histology showing HOXC10 expression in case 5 is shown in panel D.

of one set of tissue (case 5) is shown in D). These observations, in combination with cell culture data (Fig. 1A), demonstrated that HOXC10 is overexpressed in breast cancer and potentially upregulated in placental choriocarcinoma cells.

Notably, MCF7 and T47D are well-known ER-positive breast cancer cell lines and have been widely used for estrogen-related experiments (Jansson et al. 2006, Yau \& Benz 2008). Similarly, JAR cell is a placental choriocarcinoma cell line and placenta is known to produce various steroid hormones that are circulated to fetus as well as to the mother (Strauss et al. 1996). JAR cells are ER-positive cell line and have been previously used for steroid hormone-related studies (Wadsack et al. 2003). Thus, overexpression of HOXC10 in breast carcinoma tissue and also in JAR, MCF7, and T47D cell lines indicated that HOXC1O is potentially regulated by estrogen.

\section{Effect of estrogen and tamoxifen on HOXC10 gene expression}

To examine whether HOXC10 expression is regulated by estrogen, we exposed two different steroidogenic ER-positive cell lines such as JAR (Fig. 2) and MCF7 and an ER-negative breast cancer cell MDA-MB-231 (data not shown) with estrogen $\left(\mathrm{E}_{2}\right)$ and analyzed its impact on HOXC10 expression. We treated JAR and MCF7 cells with varying concentrations of $\mathrm{E}_{2}$, incubated for $8 \mathrm{~h}$, isolated RNA from the control and $\mathrm{E}_{2}$-treated cells, reverse transcribed into cDNA, and subjected to PCR analysis using primer specific to HOXC1O (Fig. 2 and data not shown). cDNA was also analyzed by realtime PCR for quantification (respective bottom panels). $G A P D H$ expression was analyzed as control. Our studies showed that, in JAR cells, the level of HOXC10 mRNA 
A
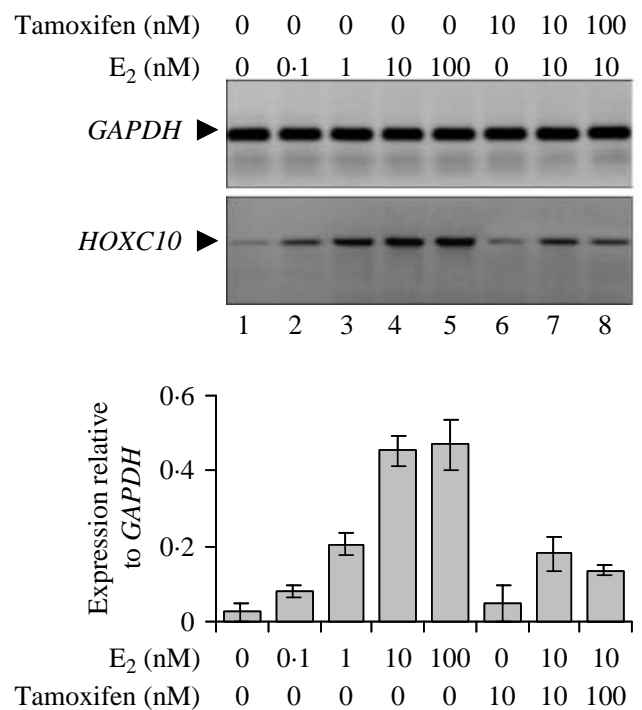

B
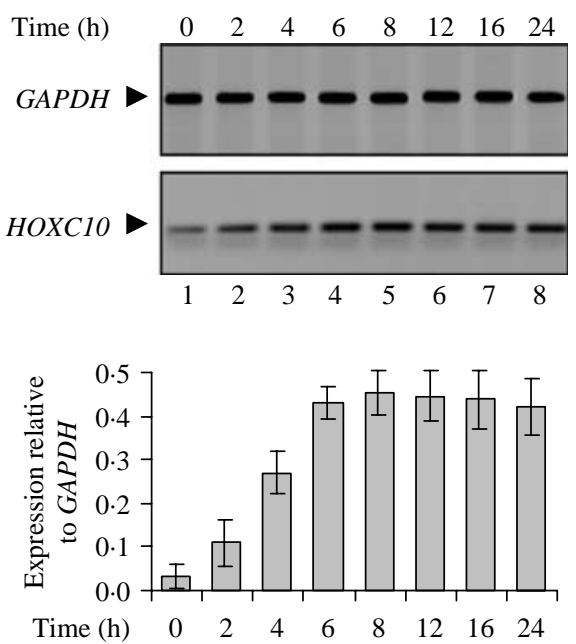

Figure 2 Effect of $E_{2}$ on $H O X C 10$ expression. (A) $E_{2}$-induced expression of $H O X C 10$ in JAR cells. The cells were grown in phenol red-free media and treated with varying concentrations of $E_{2}$ in the presence and absence of tamoxifen. The total RNA was isolated, reverse transcribed to CDNA, and analyzed by PCR using primers specific to HOXC10. GAPDH was used as a loading control. Expression of HOXC10 (relative to GAPDH) was examined by real-time PCR (bottom panel). (B) Temporal studies: JAR cells were treated with $100 \mathrm{nM} \mathrm{E}_{2}$ for varying time periods (0-24 h). RNA was reverse transcribed, analyzed by regular PCR (top panel), and real-time PCR (bottom panel). Each real-time PCR was carried out in three parallel replicates and each experiment was repeated at least thrice $(n=3)$. Bars indicate S.E.M.

was increased upon treatment with $\mathrm{E}_{2}$ in a concentration-dependent manner (Fig. 2A, real-time PCR data in bottom panel). HOXC10 expression was about

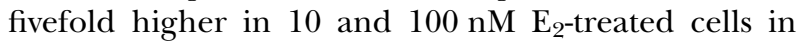
comparison with control (Fig. 2A). Importantly, application of tamoxifen, an estrogen antagonist, inhibited $\mathrm{E}_{2}$-induced expression of HOXC10 further demonstrating roles of $\mathrm{E}_{2}$ in $H O X C 10$ activation (lanes 7-8, Fig. 2A). Expression of $G A P D H$ was unaffected by $\mathrm{E}_{2}$ (Fig. 2A).

HOXC10 expression is also stimulated by $\mathrm{E}_{2}$ in MCF7 cells, though the stimulation was observed at relatively lower $\mathrm{E}_{2}$ concentration $(0 \cdot 1-1 \mathrm{nM})$ in comparison to JAR cells (data not shown). Application of tamoxifen also inhibited $\mathrm{E}_{2}$-induced expression of $\mathrm{HOXC1O}$ in MCF7 cells (data not shown). Notably, HOXC10 expression was not stimulated by $\mathrm{E}_{2}$ in an ER-negative cell line (MDA-MB-231; data not shown). The stimulation of HOXC10 expression upon exposure to $\mathrm{E}_{2}$ in two independent cell lines demonstrated that HOXC1O gene is transcriptionally regulated by $\mathrm{E}_{2}$. To determine the optimum time of $\mathrm{E}_{2}$ exposure, we treated JAR cells with $100 \mathrm{nM} \mathrm{E}_{2}$ for varying time periods and our results demonstrated that application of $\mathrm{E}_{2}$ induced HOXC1O expression as early as $2 \mathrm{~h}$ and reached a maximum at $\sim 8 \mathrm{~h}$ after $\mathrm{E}_{2}$ treatment (Fig. 2B, real-time PCR data in the bottom panel). As JAR cells showed a relatively more robust $\mathrm{E}_{2}$ response toward HOXC10 expression, we performed all other experiments in JAR cells.

\section{HOXC10 promoter contains multiple EREs}

To understand the mechanism of HOXC10 gene regulation especially under steroid hormone environment, we analyzed its promoter for the presence of any EREs. We found that HOXC1O promoter contains multiple (seven within $-3000 \mathrm{nt}$ ) putative EREs $\left(\mathrm{ERE}_{1 / 2}\right.$ sites, GGTCA, or TGACC, Fig. 3A). Notably, during estrogen-mediated gene expression, ERs bind to EREs facilitating recruitment of various transcription factors and ER coregulators leading to gene activation (Nilsson \& Gustafsson 2002). The presence of multiple $\mathrm{ERE}_{1 / 2}$ sites in $\mathrm{HOXC10}$ promoter indicated that HOXC10 is potentially regulated by estrogen. As HOXC10 showed $\mathrm{E}_{2}$ response and its promoter contains several $\mathrm{ERE}_{1 / 2}$ sites, we analyzed the $\mathrm{E}_{2}$ responsiveness of these $\mathrm{ERE}_{1 / 2}$ sites using a luciferase-based reporter assay. Initially, we cloned each $\mathrm{ERE}_{1 / 2}$ region independently in a luciferase-based reporter construct, pGL3 (Fig. 3A). A non-ERE region was also cloned as a negative control (non-ERE-pGL3, Fig. 3A). Each EREpGL3 construct was transfected in JAR cells; cells were then exposed to $\mathrm{E}_{2}$ and subjected to luciferase activity analysis using a commercial luciferase detection kit. We also cotransfected a renilla luciferase construct (pRLTk) as an internal transfection control, and luciferase activities from the ERE-pGL3 constructs were normalized relative to renilla expression. Our results demonstrated that transfection with either 


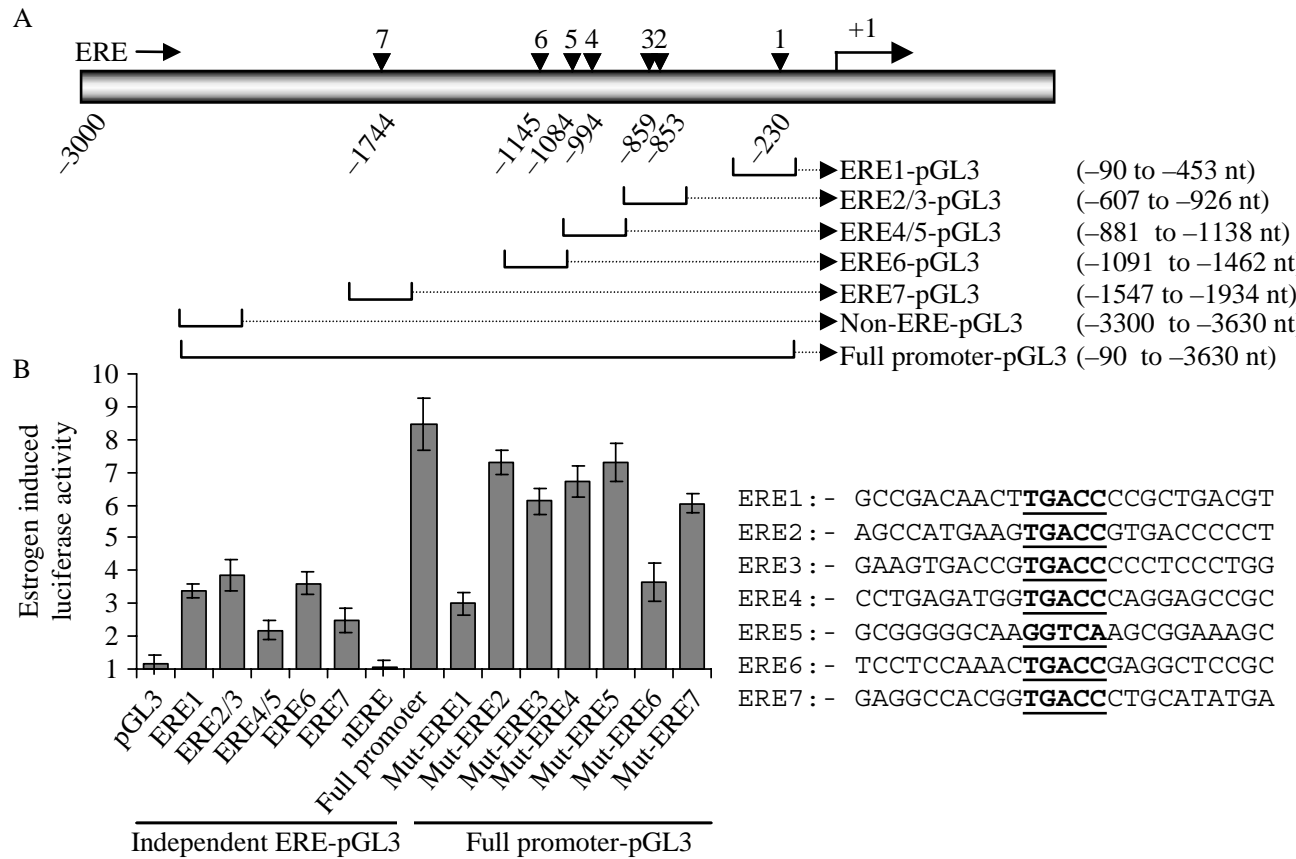

Figure 3 Characterization of HOXC10 promoter EREs using luciferase assay. (A) HOXC10 promoter showing different EREs $\left(\mathrm{ER}_{1 / 2}\right.$ sites). Each ERE (1-7), a non-ERE region, and a full-length HOXC10 promoter region were cloned into luciferase-based reporter construct, pGL3. EREs (1-7) were also mutated independently in the full-length promoter pGL3 construct and subjected to luciferase assay. (B) Luciferase assay: each ERE-pGL3 or full-length promoter pGL3 or ERE-mutated pGL3 constructs were transfected into JAR cells for $24 \mathrm{~h}$. Control cells were treated with empty pGL3 vector or non-ERE-pGL3. Cells were also cotransfected with renilla luciferase expression construct as an internal transfection control. Cells were then treated with $100 \mathrm{nM} \mathrm{E}_{2}$ and subjected to luciferase assay by using Dual-Glo Luciferase Assay System (Promega). The luciferase activities in the presence of $E_{2}$ (over untreated controls and normalized against renilla luciferase expression) were plotted. The experiment with four replicate treatments was repeated at least thrice $(n=3)$. Bars indicate S.E.M. $(P<0.05)$.

control pGL3 (no-ERE) or non-ERE-pGL3 did not induce any significant luciferase activity in the presence of $\mathrm{E}_{2}$ (Fig. 3B). However, transfection with different ERE(1-7)-pGL3 constructs resulted in $\mathrm{E}_{2}$-dependent luciferase induction, though the extent of luciferase induction was different for different EREs (Fig. 3B). ERE1-, ERE2/3-, and ERE6-pGL3 showed a more robust response to $\mathrm{E}_{2}$ (Fig. 3B).

We also cloned the full-length HOXC10 promoter spanning all the EREs in the pGL3 vector (Fig. 3A) and introduced independent mutation (GGTCA to AATCA or TGACC to TGAAA) to each $\mathrm{ERE}_{1 / 2}$ site and examined their $\mathrm{E}_{2}$ response using luciferase assay. Our results demonstrated that full-length HOXC1O promoter is about eightfold more responsive to $\mathrm{E}_{2}$ exposure compared with empty pGL3, and this $\mathrm{E}_{2}$ response is higher than the $\mathrm{E}_{2}$ response of each individual ERE examined separately (Fig. 3B). Mutation of $\mathrm{ERE}_{1 / 2}$ sites (specifically ERE1 and ERE6) resulted in significant loss of $\mathrm{E}_{2}$-dependent luciferase induction (Fig. 3B). Notably, though the individually cloned $\mathrm{ERE}_{1 / 2}$ sites (ERE2/3, ERE4/5, and ERE7) showed a significant $\mathrm{E}_{2}$ response, a point mutation in either of those EREs in a full-length promoter construct did not exhibit a major reduction in $\mathrm{E}_{2}$-dependent luciferase induction (Fig. 3B). These observations suggested that ERE1 and ERE6 regions of HOXC10 promoter are potentially involved in transcriptional regulation of HOXC10 expression in the presence of estrogen.

\section{ERs play critical roles in $\mathrm{E}_{2}$-mediated activation of HOXC10}

ERs are key players in estrogen-mediated gene activation (Nilsson et al. 2001, Lalmansingh \& Uht 2008). ER $\alpha$ and ER $\beta$ are two major ERs that regulate estrogen-responsive genes (Nilsson et al. 2001, Lalmansingh \& Uht 2008). To understand the importance of $\mathrm{ERs}$ in $\mathrm{E}_{2}$-induced expression of HOXC10, we knocked down both ER $\alpha$ and ER $\beta$ separately in JAR cells using specific phosphorothioate antisense oligonucleotide (Table 1), exposed the ER knocked down cells to $\mathrm{E}_{2}$, and analyzed its impact on HOXC1O expression. A scramble antisense 


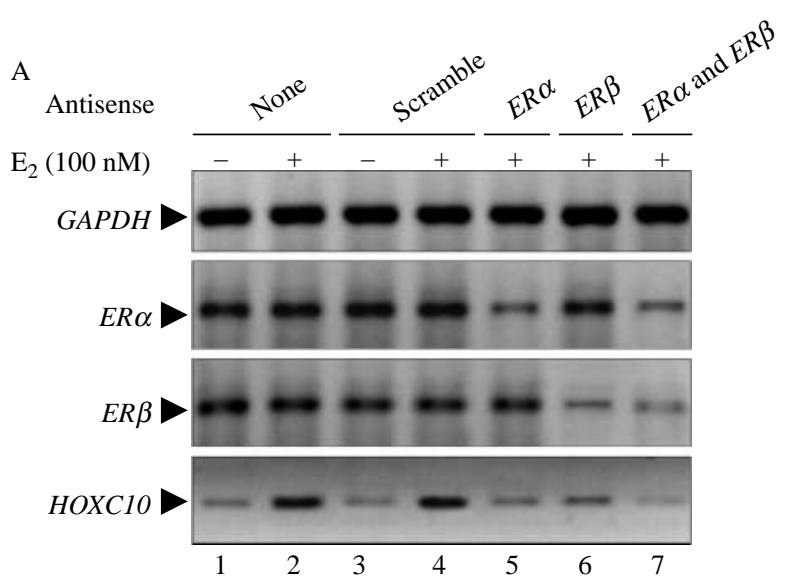

B

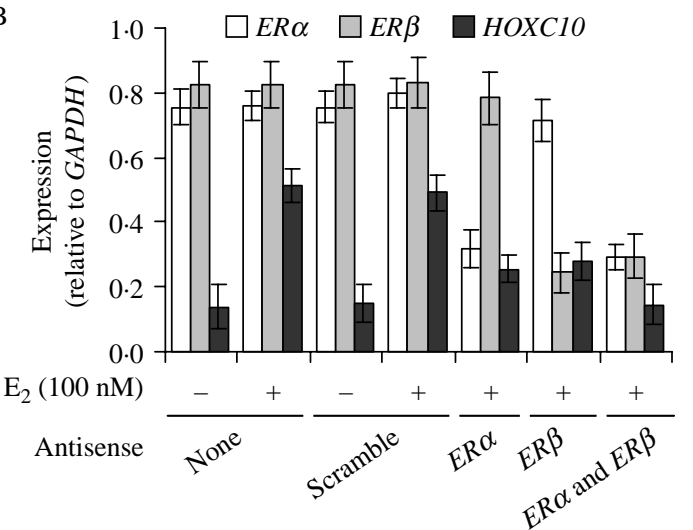

Figure 4 Effect of $E R \alpha$ and $E R \beta$ knockdown on $E_{2}$-induced expression of $H O X C 10$. JAR cells were transfected with Er $\alpha$ - and $E R \beta$-specific antisense oligonucleotide for $48 \mathrm{~h}$. A scramble antisense (with no homology with $E R \alpha$ and $E R \beta$ gene) was used as control. The knocked down cells were treated with $E_{2}$ for additional $8 \mathrm{~h}$. RNA from these cells was subjected to RT-PCR analysis by using primer specific to $H O X C 10$ along with respective $E R \alpha$ and $E R \beta$. GAPDH was used as control. (A) Lane 1: control cells; lane 2: cell treated with $E_{2}$; lanes 3-4: cells treated with scramble-antisense in the absence and presence of $E_{2}$; lanes 5-6: cells treated with $E R \alpha$ and $E R \beta$ antisense, respectively, followed by exposure to $E_{2}$; lane 7: cells transfected with a mixture (1:1) of $E R \alpha$ and $E R \beta$ antisense, respectively, followed by exposure to $E_{2}$. The real-time quantification of the transcript accumulation relative to GAPDH was plotted in bottom panel. (B) Each real-time PCR was carried out in three parallel replicates and each experiment was repeated at least thrice $(n=3)$.

Bars indicate S.E.M. $(P<0.05)$.

(with no homology to ER) was used as a negative control. Our results demonstrated that application of $\mathrm{ER} \alpha$ or $\mathrm{ER} \beta$ antisense knocked down the respective mRNA (lanes 5-6, Fig. 4A, real-time PCR data in B). Importantly, upon ER $\alpha$ or ER $\beta$ knockdown, $\mathrm{E}_{2}$-induced expression of HOXC1O was suppressed significantly (lanes 5-6, Fig. 4A and B). Application of scramble antisense did not have any significant effect on $\mathrm{E}_{2}$-mediated activation of HOXC1O (lanes 3-4,
Fig. 4A and B). Combined knockdown of ER $\alpha$ and ER $\beta$ suppressed further (almost to the basal level) the $\mathrm{E}_{2}$-dependent activation of HOXC10 (lane 7, Fig. 4A and B). Notably, the basal expression of HOXC10 may not depend on $\mathrm{E}_{2}$ and ER. These results demonstrated that both $\mathrm{ER} \alpha$ and $\mathrm{ER} \beta$ are critical players in $\mathrm{E}_{2}$-mediated transcriptional activation of HOXC1O.

\section{Roles of MLL histone methylases in $\mathrm{E}_{\mathbf{2}}$-mediated activation of HOXC10}

As MLLs are well-known players in HOX gene regulation (Guenther et al. 2005) and are also involved in nuclear receptor-mediated gene expression (Lee et al. 2006, 2009, Mo et al. 2006, Ansari \& Mandal 2010), we examined whether MLLs are also involved in HOXC10 gene activation under an $\mathrm{E}_{2}$ environment. We knocked down different MLLs (MLL1, MLL2, MLL3, and MLL4) separately by using specific phosphorothioate antisense oligonucleotide (Table 1), treated with $\mathrm{E}_{2}$, and analyzed their effect on $\mathrm{E}_{2}$ mediated activation of HOXC10. Knockdown of each MLL was confirmed both at mRNA (compare lane 4 with lane 1, Fig. 5A-D for MLL1-4 respectively) and at protein levels (data not shown). A scramble antisense (with no homology to MLL1-4) was used in parallel as a negative control. Our results demonstrated that application of MLL1 and MLL2 antisenses efficiently knocked down their respective mRNA (Fig. 5A and B, real-time PCR data in the bottom panels). However, MLL1 and MLL2 knockdown have no significant effect on $\mathrm{E}_{2}$-induced expression of HOXC10 (Fig. 5A and B, real-time PCR in bottom panels). In contrast, knockdown of MLL3 or MLL4 suppressed (more than 75\%) the $\mathrm{E}_{2}$-induced expression of $\mathrm{HOXC1O}$ (Fig. $5 \mathrm{C}$ and $\mathrm{D}$, real-time PCR data in bottom panels). These results demonstrated that MLL3 and MLL4 are critical players in $\mathrm{E}_{2}$-dependent activation of HOXC1O.

\section{Binding of ERs and MLLs into HOXC10 promoter EREs in the presence of $E_{2}$ in vivo}

As HOXC10 promoter contains seven $\mathrm{ERE}_{1 / 2}$ sites, and MLLs and ERs are involved in $\mathrm{E}_{2}$-dependent HOXC1O activation, we analyzed $\mathrm{E}_{2}$-dependent binding of ERs and MLLs into these ERE regions in vivo using ChIP assay. Initially, JAR cells were treated with $\mathrm{E}_{2}$, fixed with formaldehyde, and subjected to ChIP assay using antibodies specific to $\mathrm{ER} \alpha, \mathrm{ER} \beta$, and $\beta$-actin (as negative control). Immunoprecipitated DNA fragments were PCR amplified using primers specific to ERE1-ERE7 and a non-ERE region of HOXC10 promoter. ChIP DNA was also analyzed by real-time PCR for relative quantification. As shown in Fig. 6A, no significant binding of $\beta$-actin was observed in any EREs irrespective 

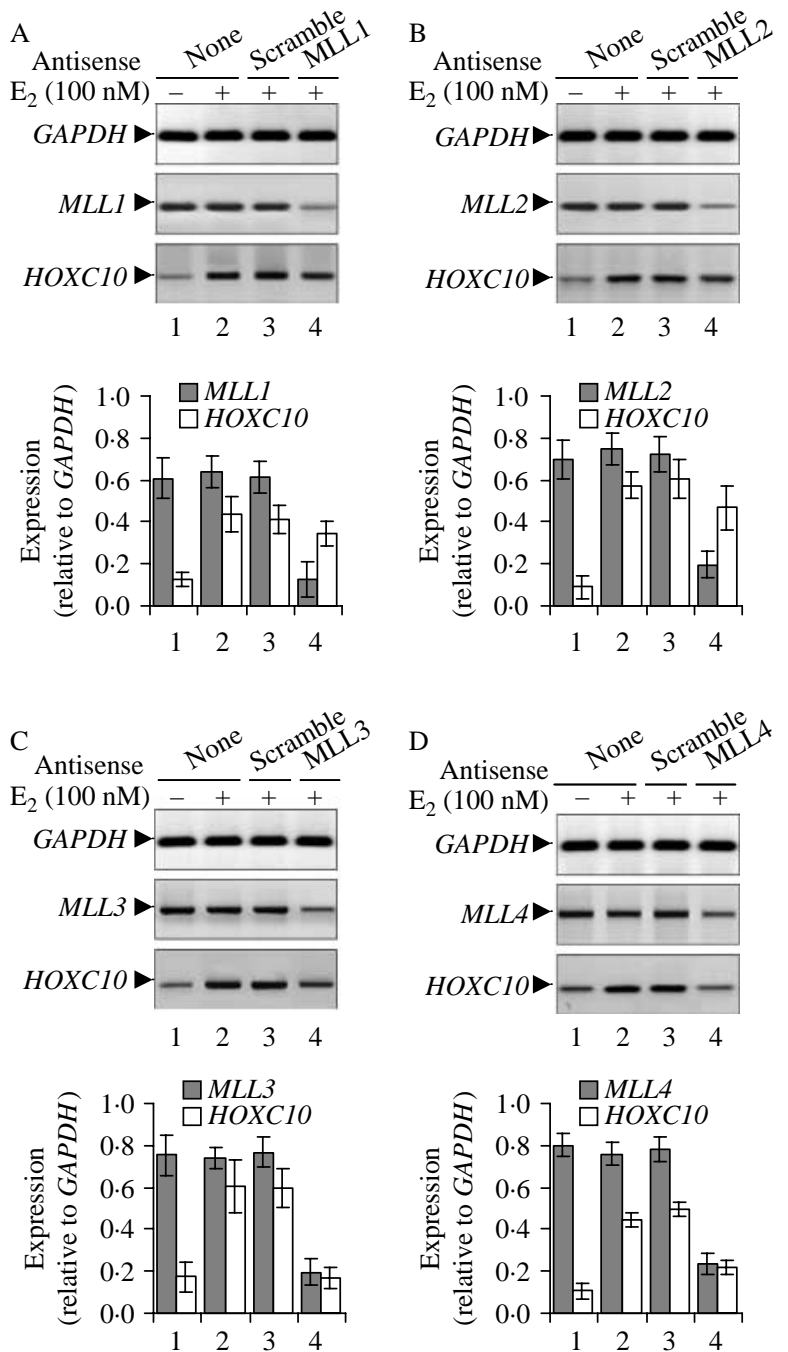

Figure 5 Effect of knockdown of $M L L s$ (1-4) on $E_{2}$-induced expression of HOXC10. JAR cells were transfected with different MLL-specific and scramble antisenses $(5 \mu \mathrm{g})$ for $48 \mathrm{~h}$ followed by treatment with $100 \mathrm{nM} \mathrm{E}_{2}$ for $8 \mathrm{~h}$. RNA was subjected to RT-PCR analysis by using primer specific to HOXC10, MLLs (1-4), and GAPDH (as control). RT-PCR products were analyzed by agarose gel and quantified by using real-time PCR (bottom panels). (A) Effects of MLL1 knockdown. Lane 1: control cells; lane 2: cells treated with $100 \mathrm{nM} \mathrm{E}_{2}$; lanes 3-4: cells transfected with scramble and MLL1 antisense, respectively, followed by treatment with $E_{2}$. Quantification of transcript accumulation (MLL1 or HOXC10) based on real-time PCR analysis is shown in the bottom panel. (B-D) Effects of knockdown of MLL2, MLL3, and MLL4 respectively (using similar experiments as described in $A$ ). Real-time PCR quantifications are shown in the respective bottom panels. Each real-time PCR was carried out in three parallel replicates and each experiment was repeated at least thrice $(n=3)$. Bars indicate S.E.M. $(P<0.05)$.

of $\mathrm{E}_{2}$ (Fig. 6A). No binding of $\mathrm{ER} \alpha$ and $\mathrm{ER} \beta$ was observed in HOXC10 promoter region containing no ERE (non-ERE). However, binding of $\mathrm{ER} \alpha$ and $\mathrm{ER} \beta$ was enhanced in the ERE1 region in an $E_{2}$-dependent manner (Fig. 6A, real-time PCR quantifications of ChIP DNA are shown in $\mathrm{B}$ ). An $\mathrm{E}_{2}$-dependent increase in $\mathrm{ER} \alpha$ binding was also observed in ERE6 region (Fig. 6A and $\mathrm{B}$ ). Constitutive binding of $\mathrm{ER} \alpha$ and $\mathrm{ER} \beta$ was observed in ERE3, 4, and 7 regions. No binding of ER $\alpha$ and ER $\beta$ was observed in ERE2 and ERE5 irrespective of $\mathrm{E}_{2}$. These results demonstrated that ERE1 and ERE6 are likely involved in $\mathrm{E}_{2}$-dependent activation of HOXC10 in vivo. As ERE1 and ERE6 were found to be more responsive to $\mathrm{E}_{2}$ treatment, we performed all other binding analysis on these two ERE regions only.

As MLL3 and MLL4 (but not MLL1 and MLL2) were found to be essential in $\mathrm{E}_{2}$-dependent activation of HOXC10, we examined the binding of these MLLs into $\mathrm{E}_{2}$-responsive ERE1 and ERE6 regions using the ChIP assay. We observed that binding of MLL3 and MLL4 was enhanced upon addition of $\mathrm{E}_{2}$ in both ERE1 and ERE6 regions; however, no $\mathrm{E}_{2}$-dependent recruitment of MLL1 and MLL2 was observed in either of these EREs (Fig. 6C and D, real-time PCR data in bottom panel). These observations further suggested that MLL3 and MLL4 regulate HOXC10 gene expression in the presence of $\mathrm{E}_{2}$, likely via interaction with ERE1 and ERE6 regions of $\mathrm{HOXC10}$ promoter.

Temporal studies demonstrated that $\mathrm{ER} \alpha$ and $\mathrm{ER} \beta$ were bound to ERE1 and ER $\alpha$ in ERE6 regions in an $\mathrm{E}_{2^{-}}$ and time-dependent manner (Fig. 7A). $\mathrm{E}_{2}$-induced binding of $\mathrm{ER} \alpha$ was observed as early as 15 min after $\mathrm{E}_{2}$ treatment in both ERE1 and ERE6 regions, while binding of ER $\beta$ (to ERE1) was delayed ( $\sim 2 \mathrm{~h}$; Fig. 7A). MLL3 and MLL4 were also bound to the ERE1 and ERE6 regions in an $\mathrm{E}_{2}$ - and time-dependent manner (Fig. 7A). The binding of MLL3 was increased as early as $30 \mathrm{~min}$ in both ERE1 and ERE6; however, binding of MLL4 was slightly delayed (Fig. 7A). Similar to MLL3 and MLL4, we also observed the concomitant increase in RNA polymerase II (RNAP II) recruitment and H3K4 trimethylation level in ERE1 and ERE6 regions indicating the involvement of histone H3K4 trimethylation activities in $\mathrm{E}_{2}$-mediated activation of HOXC10 (Fig. 7A).

To examine potential roles of MLL3 and MLL4 in $\mathrm{E}_{2}$-mediated HOXC10 activation, we examined the level of H3K4 trimethylation and RNAPII recruitment (ChIP assay) at the HOXC10 promoter after MLL3 and MLL4 knockdowns followed by $\mathrm{E}_{2}$ treatment. Our results demonstrated that upon knockdown of either MLL3 or MLL4, or their combined knockdown, the level of H3K4 trimethylation and RNAPII recruitment at the ERE1 and ERE6 regions of HOXC10 promoter was decreased significantly (Fig. 7B and C). These observations indicated that MLL3 and MLL4 mediate histone H3K4 trimethylation and RNAPII recruitment at the HOXC1O promoter in the presence of $\mathrm{E}_{2}$ and induce transcription activation. 


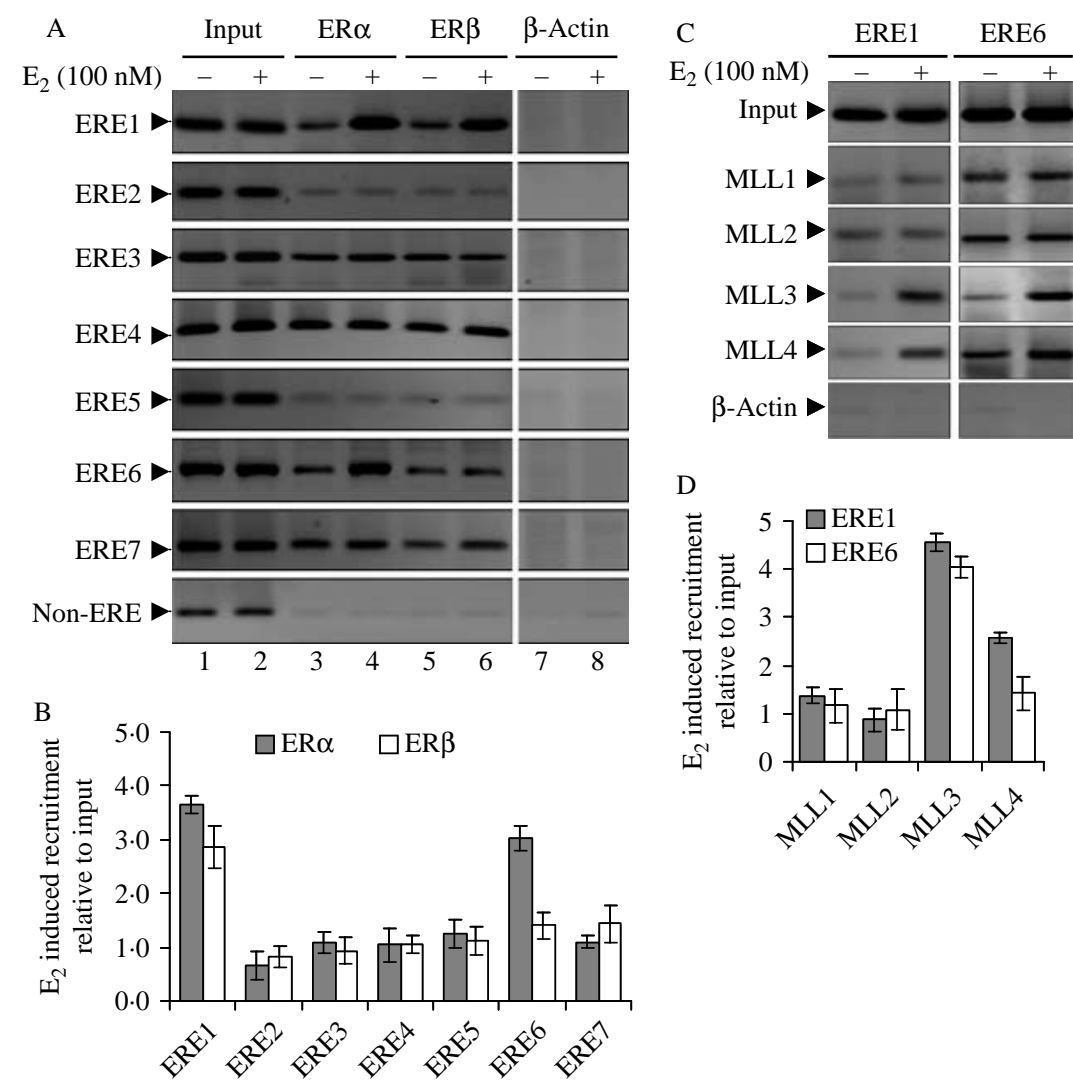

Figure $6 \mathrm{E}_{2}$-dependent recruitment of ERs and MLLs onto HOXC10 EREs. (A and B) JAR cells were treated with $100 \mathrm{nM} \mathrm{E}_{2}$ for $8 \mathrm{~h}$ and analyzed by ChIP assay using ER $\alpha$ and ER $\beta$ antibodies. $\beta$-Actin antibody was used as control IgG. The ChIP DNA was PCR amplified using primers specific to different ERE regions (ERE1-ERE7) or a non-ERE region of $H O X C 10$ promoter. Real-time quantification of ChIP DNA samples showing the recruitment of $E R \alpha$ and $E R \beta$ (relative to input) into different $E R E$ regions in the presence of $E_{2}$ is shown in panel $B$. ( $C$ and $\left.D\right) E_{2}$-dependent binding of MLLs on ERE1 and ERE6 of $\mathrm{HOXC10}$ promoter. JAR cells were treated with $100 \mathrm{nM} \mathrm{E}_{2}$ for $8 \mathrm{~h}$ and analyzed by ChIP assay using MLL1-, MLL2-, MLL3-, MLL4-, and $\beta$-actin (control)-specific antibodies. The immunoprecipitated DNA fragments were PCR amplified using primers specific to ERE1 and ERE6 regions of HOXC10 promoter. Real-time quantification of the recruitment of MLL1-4 relative to input was plotted in panel D. The experiments were repeated at least twice. Bars indicate S.E.M.

\section{MLL3 and MLL4 are recruited to the HOXC10 EREs in an ER-dependent manner}

ERs have an activation domain and DNA-binding domain and they are well known to bind directly to EREs of estrogen-responsive genes via their DNAbinding domain (Nilsson \& Gustafsson 2002). Notably, MLL3 and MLL4 also have DNA-binding domains that may facilitate their direct binding to the ERE sequences. MLL3 and MLL4 also have multiple NR boxes that are responsible for interaction with nuclear receptors (Ansari et al. 2009a,b,c). In fact, MLL3 and MLL4 were recently shown to be recruited to LXR gene promoter regulating its expression (Lee et al. 2009). Herein, to examine the mode of binding of MLL3 and
MLL4 to the HOXC10 promoter, we knocked down ER $\alpha$ and ER $\beta$ separately in JAR cells, then exposed to $\mathrm{E}_{2}$, and analyzed the status of MLL3 and MLL4 recruitment to ERE1 and ERE6 (Fig. 8, real-time PCR data of ChIP DNA samples is in the bottom panel). As expected, we found that the binding of MLL3 and MLL4 was increased in both ERE1 and ERE6 regions of HOXC10 promoter in the presence of $\mathrm{E}_{2}$ and scramble antisense (lanes 1 and 2, Fig. 8). However, knockdown of either $\mathrm{ER} \alpha$ or ER $\beta$ decreased (or even abolished) the recruitment of MLLs onto both ERE1 and ERE6 regions (compare lanes 3 and 4, with lane 2, Fig. 8). These results suggest that recruitment of MLL3 and MLL4 to the HOXC10 EREs is dependent on both ER $\alpha$ and ER $\beta$. 

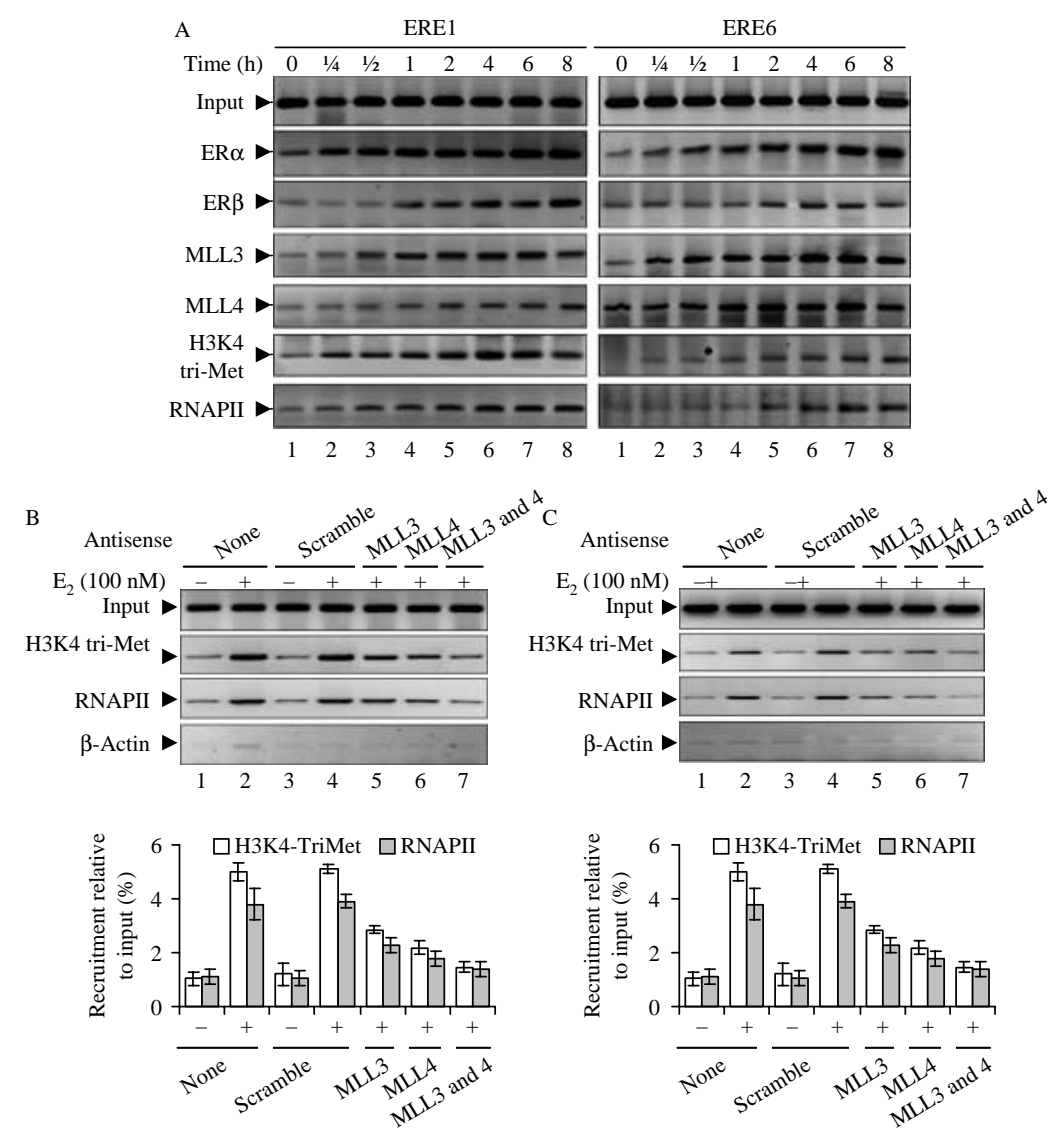

Figure 7 (A) Temporal recruitment of ERs, MLLs, RNAPII, and level of H3K4 trimethyl in the ERE1 and ERE6 regions of HOXC10 promoter. Cells were treated with $100 \mathrm{nM}$ $\mathrm{E}_{2}$ for varying time periods and analyzed by ChIP assay using $\mathrm{ER} \alpha, \mathrm{ER} \beta, \mathrm{MLL} 3$, MLL4, H3K4-trimethyl, and RNAPII antibodies. The ChIP DNA was PCR amplified using primers specific to ERE1 and ERE6 regions of HOXC10 promoter. (B and C) Effect of MLL3 and MLL4 knockdown on H3K4 trimethylation and RNAPII recruitment. JAR cells were treated with MLL3 and MLL4 antisenses for $48 \mathrm{~h}$ followed by $E_{2}$ treatment for $8 \mathrm{~h}$. Cells were fixed and subjected to ChIP analysis by using antibodies specific to H3K4 trimethyl and RNAPII. $\beta$-Actin antibody was used as control IgG. The immunoprecipitated DNA fragments were PCR amplified using primers specific to ERE1 and ERE6 regions of HOXC10 promoter. Real-time PCR quantifications are shown in respective bottom panel. Experiments were repeated at least twice $(n=2)$ and bars indicate S.E.M.

\section{Discussion}

A growing body of evidence suggests that hormones play critical roles in regulation of developmental genes including HOX genes (Ma et al. 1998, Lim et al. 1999, Huang et al. 2007). For example, retinoic acids affect $H O X$ gene expression and produce homeotic transformation (Huang et al. 2007). Although retinoids regulate anterior $H O X$ genes, recent data showed that posterior $H O X$ genes are regulated by estrogens and progesterones (Lim et al. 1999). Neonatal exposure to diethylstilbestrol (DES) downregulates uterine Hoxa10 expression (Ma et al. 1998). Hoxb13, a gene that is involved in normal differentiation and secretory function of the mouse ventral prostate, is suppressed upon exposure to neonatal estrogen (Economides et al. 2003). Ovariectomy in mouse affects the expression of Hoxc6, which is critical for mammary gland development and milk production (Garcia-Gasca \& Spyropoulos 2000). Beyond their developmental roles, expression of several HOX genes is associated with breast and prostate cancers that are highly sensitive to steroid hormones (Huang et al. 2007).

Hoxc10 is a critical gene that is involved in the development of spinal cord, formation of neurons, and associated with human leukemia (Akbas et al. 2004, Choe et al. 2006, Lopez et al. 2006, Zhai et al. 2007). The mechanism by which HOXC10 expression is regulated is 

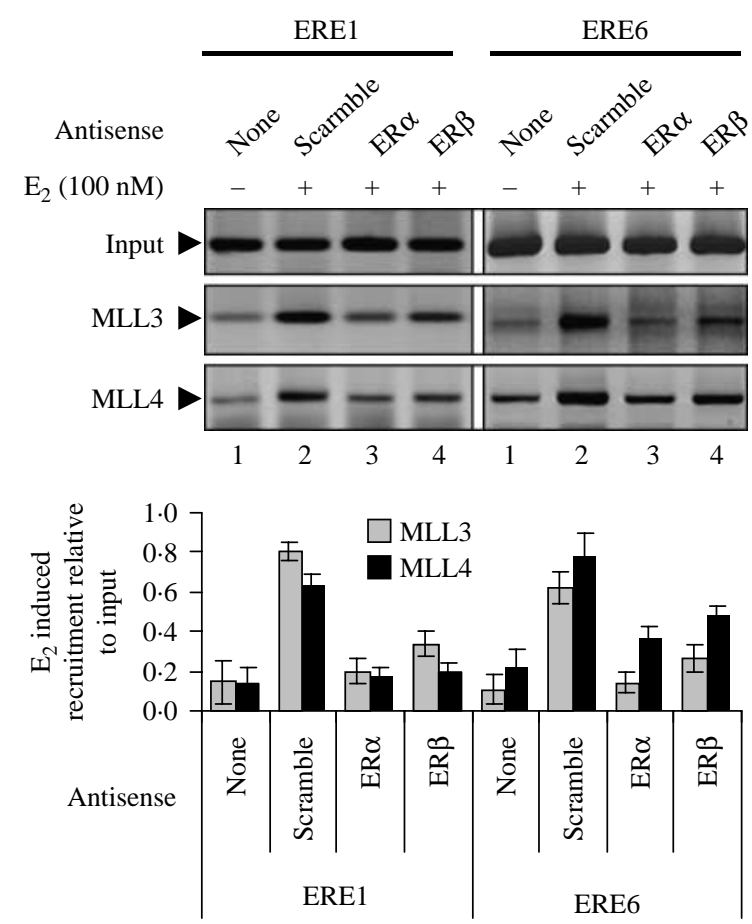

Figure 8 Effects of ER $\alpha$ and ER $\beta$ knockdown on $E_{2}$-dependent recruitment of MLL3 and MLL4. JAR cells were transfected with $\mathrm{ER} \alpha, \mathrm{ER} \beta$, and scramble antisenses ( $9 \mu \mathrm{g}$ each) for $48 \mathrm{~h}$ followed by treatment with $100 \mathrm{nM} \mathrm{E}_{2}$ for $6 \mathrm{~h}$. Cells were subjected to ChIP assay using MLL3 and MLL4 antibodies and immunoprecipitated DNA fragments were PCR amplified using primers specific to ERE1 and ERE6 regions of HOXC10 promoter. Real-time quantification of ChIP DNA samples is shown in the bottom panel. Experiments were repeated at least twice and bars indicate S.E.M.

unknown. Notably, ovarian hormones are known to influence spinal cord physiology (Monks et al. 2001). Our studies demonstrated that expression of HOXC1O is significantly higher in human breast cancer tissue. In agreement with our finding, recent studies showed that along with various other genes, HOXC10 transcripts were overexpressed in lymph node $(+)$ breast carcinomas (Abba et al. 2007). HOXC10 expression was also higher in different ER-positive breast and placental choriocarcinoma cells, in comparison to various nonmalignant cell lines, indicating potential roles of estrogen in transcriptional regulation of HOXC1O. Our studies demonstrated that upon exposure to estrogen $\left(\mathrm{E}_{2}\right)$, HOXC10 is transcriptionally activated in both ER-positive breast (MCF7) and placenta choriocarcinoma (JAR) cells. HOXC10 gene promoter contains several $\mathrm{ERE}_{1 / 2}$ sites and luciferase-based reporter assay demonstrated that HOXC1O promoter (full promoter) is highly responsive to $\mathrm{E}_{2}$ exposure. Mutation in the ERE1 and ERE6 regions of HOXC10 promoter significantly affected its $E_{2}$ sensitivity indicating potential involvement of these EREs in $\mathrm{E}_{2}$-mediated transcriptional activation of HOXC10. Notably, the luciferase reporter assay is based on recombinant plasmid DNA constructs that do not represent native chromatin environment present inside the cell, and therefore, these luciferase-based data may not be directly correlated with $\mathrm{E}_{2}$ responses of different EREs in vivo. Notably, in agreement with the luciferase data, analysis of the binding of ER and ER coregulators (MLL3 and MLL4 in this case) demonstrated that primarily ERE1 and ERE 6 of HOXC10 promoter are most responsive to $\mathrm{E}_{2}$-dependent binding of ERs and MLLs, and may be involved in $\mathrm{E}_{2}$-induced regulation of HOXC1O in vivo.

ERs are major players in regulation of estrogenresponsive genes (Nilsson et al. 2001). In an EREdependent mechanism, in the presence of estrogen, ERs bind to the ERE sequences and mediate gene activation (Nilsson et al. 2001). Our results demonstrated that antisense-mediated knockdown of either $\mathrm{ER} \alpha$ or $\mathrm{ER} \beta$ abolished $\mathrm{E}_{2}$-induced activation of HOXC10. ChIP analysis demonstrated that both ER $\alpha$ and ER $\beta$ are recruited to ERE1 and ER $\alpha$ in the ERE6 region of HOXC1O promoter in an $\mathrm{E}_{2}$-dependent manner. These observations demonstrated that ERs are involved in $\mathrm{E}_{2}$-induced expression of HOXC10. Notably, as seen in Fig. $6 \mathrm{~A}$ and $\mathrm{B}$, some amount of constitutive bindings of $E R \alpha$ and $E R \beta$ was observed in the ERE3, ERE4, and ERE7 region and this binding was not altered by $E_{2}$. These observations suggest that these EREs could be associated with basal transcription of HOXC10.

Importantly, when activated ERs bind to the promoters, they also recruit various activators and coactivators that lead to structural changes and remodeling of the chromatin leading to transcription activation (Lonard \& O'Malley 2007). Recent studies demonstrated that histone methylases MLL2, MLL3, and MLL4 act as a coactivator for ERs in regulation of certain $\mathrm{E}_{2}$-responsive genes (Mazo et al. 1990, Dreijerink et al. 2006, Mo et al. 2006, Ansari et al. 2009a,b,c). Notably, protein containing LXXLL domain (NR box) is known to interact with NRs and play critical roles in ligand-dependent gene activation (Ansari et al. $2009 a, b, c)$. Sequence analysis showed that MLL1 contains one LXXLL domain, while MLL2, MLL3, and MLL4 contain at least four NR boxes indicating their potential involvement in $\mathrm{E}_{2}$-mediated regulation of estrogen-responsive genes (Ansari et al. 2009a,b,c). Our studies demonstrated that, similar to ER $\alpha$ and ER $\beta$, knockdown of MLL3 and MLL4 resulted in downregulation of $\mathrm{E}_{2}$-dependent activation of HOXC1O.

ChIP analysis demonstrated that MLL3 and MLL4 were bound to ERE1 and ERE6 regions of HOXC10 promoter in an $\mathrm{E}_{2}$-dependent manner. In contrast, $\mathrm{E}_{2}$-dependent binding of MLL1 and MLL2 was not observed, further indicating no significant roles of MLL1 and MLL2 in the process. These observations demonstrated that MLL3 and MLL4 play critical roles in $\mathrm{E}_{2}$-dependent activation of $\mathrm{HOXC1O}$ and this may be 
mediated via binding to ERE1 and ERE6 regions of HOXC10. Importantly, knockdown of either MLL3 or MLL4 abolishes the $\mathrm{E}_{2}$-dependent enrichment of H3K4 trimethylation and recruitment of RNA polymerase II at the HOXC10 promoter, indicating critical roles of MLL3 and MLL4 in promoter histone H3K4 trimethylation and transcription initiation.

Furthermore, our results demonstrated that knockdown of ERs (ER $\alpha$ or ER $\beta)$ resulted in decreased binding of MLL3 and MLL4 into the EREs of HOXC10 gene promoter, indicating critical roles of $\mathrm{ER} \alpha$ and $\mathrm{ER} \beta$ in recruiting MLL3 and MLL4 in the HOXC10 promoter. Notably, in addition to LXXLL domains, MLL3 and MLL4 also contain a DNA-binding domain that may also facilitate their recruitment to their target gene promoters. MLL2 also has NR boxes and has been previously implicated in ER-associated gene activation. However, based on our experiments, MLL2 is not involved in $\mathrm{E}_{2}$-dependent activation of HOXC1O. This is likely because different genes may have different coregulator requirements, and based on our data, MLL3 and MLL4 are the ER coregulators for HOXC10. Notably, Lee et al. (2006), has demonstrated that MLL3 and MLL4 (but not MLL1 and MLL2) are involved in hormone-mediated regulation of $R A R \beta$. Furthermore, our studies demonstrated that both ER $\alpha$ and $\mathrm{ER} \beta$ are involved in $\mathrm{E}_{2}$-mediated activation of HOXC10. These observations indicate that $\mathrm{ER} \alpha$ and ER $\beta$ may form a heterodimer that recognizes the EREs in the HOXC10 promoter. Our results also showed that knockdown of either ER $\alpha$ or ER $\beta$ did not completely abolish the $\mathrm{E}_{2}$-dependent activation of HOXC1O expression. This observation suggests that both ER $\alpha$ and ER $\beta$ can supplement the function of each other while one ER is specifically knocked down. This is likely mediated via formation of a homodimer (instead of a heterodimer) that binds the promoter EREs and helps the recruitment of ER coactivators. Notably, the ERs are well known to form the homo- and heterodimers in recognition of EREs during transcriptional regulation of estrogen-responsive genes (Nilsson \& Gustafsson 2002, Lindberg et al. 2003).

Overall, our studies demonstrated that HOXC1O is overexpressed in breast cancer tissue and is transcriptionally activated by estrogen. Histone methylases MLL3 and MLL4 coordinate with ERs and play critical roles in transcriptional regulation of HOXC1O in the presence of estrogen. Though MLLs are considered major regulators of $H O X$ genes, little is known about their roles in regulation of $H O X$ genes in a hormonal environment. Our studies revealed novel roles of MLL histone methylases in estrogen-mediated regulation of HOX genes. Notably, Hoxa10, a Hoxc10 paralogous gene, has been previously shown to be regulated by estrogen and is critical in endometrial differentiation and uterine development (Taylor et al. 1998).
$\mathrm{E}_{2}$-dependent Hoxa10 expression is tissue specific and mediated via involvement of ERs and specificity factor Sp1 (Martin et al. 2007). Our studies demonstrated that HOXC1O is also an estrogen-responsive gene and this may be associated with hormone-induced cell differentiation, development, and human diseases.

\section{Declaration of interest}

The authors declare that there is no conflict of interest that could be perceived as prejudicing the impartiality of the research reported.

\section{Funding}

Research in Mandal Laboratory is supported in parts by grants from NIH (1R15 ES019129-01, 2R15 CA113747-02), NSF (0821969), and American Heart Association (0765160Y).

\section{Acknowledgements}

The authors thank Arunoday Bhan and other laboratory members for helpful discussions.

\section{References}

Abba MC, Sun H, Hawkins KA, Drake JA, Hu Y, Nunez MI, Gaddis S, Shi T, Horvath S, Sahin A et al. 2007 Breast cancer molecular signatures as determined by SAGE: correlation with lymph node status. Molecular Cancer Research 5 881-890. (doi:10.1158/1541-7786. MCR-07-0055)

Agger K, Christensen J, Cloos PA \& Helin K 2008 The emerging functions of histone demethylases. Current Opinion in Genetics $\mathcal{E}$ Development 18 159-168. (doi:10.1016/j.gde.2007.12.003)

Akbas GE, Song J \& Taylor HS 2004 A HOXA10 estrogen response element (ERE) is differentially regulated by 17 beta-estradiol and diethylstilbestrol (DES). Journal of Molecular Biology 340 1013-1023. (doi:10.1016/j.jmb.2004.05.052)

Alexander T, Nolte C \& Krumlauf R 2009 Hox genes and segmentation of the hindbrain and axial skeleton. Annual Review of Cell and Developmental Biology 25 431-456. (doi:10.1146/annurev.cellbio. 042308.113423)

Ansari KI \& Mandal SS 2010 Mixed lineage leukemia: roles in gene expression, hormone signaling and mRNA processing. FEBS Journal 277 1790-1804. (doi:10.1111/j.1742-4658.2010.07606.x)

Ansari KI, Mishra BP \& Mandal SS 2008 Human CpG binding protein interacts with MLL1, MLL2 and hSet1 and regulates Hox gene expression. Biochimica et Biophysica Acta 1779 66-73. (doi:10.1016/ j.bbagrm.2007.11.006)

Ansari KI, Hussain I, Das HK \& Mandal SS 2009a Overexpression of human histone methylase MLL1 upon exposure to a food contaminant mycotoxin, deoxynivalenol. FEBS Journal 276 3299-3307. (doi:10.1111/j.1742-4658.2009.07055.x)

Ansari KI, Kasiri S, Hussain I \& Mandal SS 2009 $b$ Mixed lineage leukemia histone methylases play critical roles in estrogenmediated regulation of HOXC13. FEBS Journal 276 7400-7411. (doi:10.1111/j.1742-4658.2009.07453.x)

Ansari KI, Mishra BP \& Mandal SS 2009c MLL histone methylases in gene expression, hormone signaling and cell cycle. Frontiers in Bioscience 14 3483-3495. (doi:10.2741/3466)

Bannister AJ \& Kouzarides T 2005 Reversing histone methylation. Nature 436 1103-1106. (doi:10.1038/nature04048) 
Bhaumik SR, Smith E \& Shilatifard A 2007 Covalent modifications of histones during development and disease pathogenesis. Nature Structural E Molecular Biology 14 1008-1016. (doi:10.1038/ nsmb1337)

Choe A, Phun HQ, Tieu DD, Hu YH \& Carpenter EM 2006 Expression patterns of Hox10 paralogous genes during lumbar spinal cord development. Gene Expression Patterns 6 730-737. (doi:10.1016/j. modgep.2005.12.004)

Crawford BD \& Hess JL 2006 MLL core components give the green light to histone methylation. ACS Chemical Biology 1 495-498. (doi:10.1021/cb600367v)

Daftary GS \& Taylor HS 2006 Endocrine regulation of HOX genes. Endocrine Reviews 27 331-355. (doi:10.1210/er.2005-0018)

Dou Y, Milne TA, Ruthenburg AJ, Lee S, Lee JW, Verdine GL, Allis CD \& Roeder RG 2006 Regulation of MLL1 H3K4 methyltransferase activity by its core components. Nature Structural \& Molecular Biology 13 713-719. (doi:10.1038/nsmb1128)

Dreijerink KM, Mulder KW, Winkler GS, Hoppener JW, Lips CJ \& Timmers HT 2006 Menin links estrogen receptor activation to histone H3K4 trimethylation. Cancer Research 66 4929-4935. (doi:10. 1158/0008-5472.CAN-05-4461)

Economides KD, Zeltser L \& Capecchi MR 2003 Hoxb13 mutations cause overgrowth of caudal spinal cord and tail vertebrae. Developmental Biology 256 317-330. (doi:10.1016/S00121606(02)00137-9)

Fu SW, Schwartz A, Stevenson H, Pinzone JJ, Davenport GJ, Orenstein JM, Gutierrez P, Simmens SJ, Abraham J, Poola I et al. 2003 Correlation of expression of BP1, a homeobox gene, with estrogen receptor status in breast cancer. Breast Cancer Research 5 R82-R87. (doi:10.1186/bcr602)

Garcia-Gasca A \& Spyropoulos DD 2000 Differential mammary morphogenesis along the anteroposterior axis in Hoxc6 gene targeted mice. Developmental Dynamics 219 261-276. (doi:10.1002/ 1097-0177(2000)9999:9999 <::AID-DVDY1048>3.0.CO;2-3)

Gehring WJ 1993 Exploring the homeobox. Gene 135 215-221. (doi:10.1016/0378-1119(93)90068-E)

Glaser S, Schaft J, Lubitz S, Vintersten K, van der Hoeven F, Tufteland KR, Aasland R, Anastassiadis K, Ang SL \& Stewart AF 2006 Multiple epigenetic maintenance factors implicated by the loss of Mll2 in mouse development. Development 133 1423-1432. (doi:10.1242/dev. 02302)

Guenther MG, Jenner RG, Chevalier B, Nakamura T, Croce CM, Canaani E \& Young RA 2005 Global and Hox-specific roles for the MLL1 methyltransferase. PNAS 102 8603-8608. (doi:10.1073/pnas. 0503072102)

Hanson RD, Hess JL, Yu BD, Ernst P, van Lohuizen M, Berns A, van der Lugt NM, Shashikant CS, Ruddle FH, Seto M et al. 1999 Mammalian trithorax and polycomb-group homologues are antagonistic regulators of homeotic development. PNAS 96 14372-14377. (doi:10.1073/pnas.96.25.14372)

Hess JL 2004 MLL: a histone methyltransferase disrupted in leukemia. Trends in Molecular Medicine 10 500-507. (doi:10.1016/j.molmed. 2004.08.005)

Huang L, Pu Y, Hepps D, Danielpour D \& Prins GS 2007 Posterior Hox gene expression and differential androgen regulation in the developing and adult rat prostate lobes. Endocrinology 148 1235-1245. (doi:10.1210/en.2006-1250)

Issaeva I, Zonis Y, Rozovskaia T, Orlovsky K, Croce CM, Nakamura T, Mazo A, Eisenbach L \& Canaani E 2007 Knockdown of ALR (MLL2) reveals ALR target genes and leads to alterations in cell adhesion and growth. Molecular and Cellular Biology 27 1889-1903. (doi:10. 1128/MCB.01506-06)

Jansson AK, Gunnarsson C, Cohen M, Sivik T \& Stal O 2006 17betahydroxysteroid dehydrogenase 14 affects estradiol levels in breast cancer cells and is a prognostic marker in estrogen receptor-positive breast cancer. Cancer Research 66 11471-11477. (doi:10.1158/00085472.CAN-06-1448)
Lalmansingh AS \& Uht RM 2008 Estradiol regulates corticotropinreleasing hormone gene (crh) expression in a rapid and phasic manner that parallels estrogen receptor-alpha and -beta recruitment to a $3^{\prime}, 5^{\prime}$-cyclic adenosine $5^{\prime}$-monophosphate regulatory region of the proximal crh promoter. Endocrinology 149 346-357. (doi:10.1210/en.2007-0372)

Lane DB, Rutherford TJ \& Taylor HS 2004 HOXA10 expression in endometrial adenocarcinoma. Tumour Biology 25 264-269. (doi:10. 1159/000081390)

Lappin TR, Grier DG, Thompson A \& Halliday HL 2006 HOX genes: seductive science, mysterious mechanisms. Ulster Medical Journal 75 23-31.

Lawrence HJ, Sauvageau G, Humphries RK \& Largman C 1996 The role of HOX homeobox genes in normal and leukemic hematopoiesis. Stem Cells 14 281-291. (doi:10.1002/stem.140281)

Lee JH \& Skalnik DG 2005 CpG-binding protein (CXXC finger protein 1) is a component of the mammalian Setl histone H3-Lys4 methyltransferase complex, the analogue of the yeast Set1/ COMPASS complex. Journal of Biological Chemistry 280 41725-41731. (doi:10.1074/jbc.M508312200)

Lee S, Lee DK, Dou Y, Lee J, Lee B, Kwak E, Kong YY, Lee SK, Roeder RG \& Lee JW 2006 Coactivator as a target gene specificity determinant for histone H3 lysine 4 methyltransferases. PNAS 103 15392-15397. (doi:10.1073/pnas.0607313103)

Lee S, Kim DH, Goo YH, Lee YC, Lee SK \& Lee JW 2009 Crucial roles for interactions between MLL3/4 and INI1 in nuclear receptor transactivation. Molecular Endocrinology 23 610-619. (doi:10.1210/ me.2008-0455)

Lim H, Ma L, Ma WG, Maas RL \& Dey SK 1999 Hoxa-10 regulates uterine stromal cell responsiveness to progesterone during implantation and decidualization in the mouse. Molecular Endocrinology 13 1005-1017. (doi:10.1210/me.13.6.1005)

Lindberg MK, Moverare S, Skrtic S, Gao H, Dahlman-Wright K, Gustafsson JA \& Ohlsson C 2003 Estrogen receptor (ER)-beta reduces ERalpha-regulated gene transcription, supporting a "ying yang" relationship between ERalpha and ERbeta in mice. Molecular Endocrinology 17 203-208. (doi:10.1210/me.2002-0206)

Lonard DM \& O'Malley BW 2007 Nuclear receptor coregulators: judges, juries, and executioners of cellular regulation. Molecular Cell 27 691-700. (doi:10.1016/j.molcel.2007.08.012)

Lopez R, Garrido E, Vazquez G, Pina P, Perez C, Alvarado I \& Salcedo M 2006 A subgroup of HOX Abd-B gene is differentially expressed in cervical cancer. International Journal of Gynecological Cancer 16 1289-1296. (doi:10.1111/j.1525-1438.2006. 00603.x)

Ma L, Benson GV, Lim H, Dey SK \& Maas RL 1998 Abdominal B (AbdB) Hoxa genes: regulation in adult uterus by estrogen and progesterone and repression in mullerian duct by the synthetic estrogen diethylstilbestrol (DES). Developmental Biology 197 141-154. (doi:10.1006/dbio.1998.8907)

Martin R, Taylor MB, Krikun G, Lockwood C, Akbas GE \& Taylor HS 2007 Differential cell-specific modulation of HOXA10 by estrogen and specificity protein 1 response elements. Journal of Clinical Endocrinology and Metabolism 92 1920-1926. (doi:10.1210/jc.20061694)

Mazo AM, Huang DH, Mozer BA \& Dawid IB 1990 The trithorax gene, a trans-acting regulator of the bithorax complex in Drosophila, encodes a protein with zinc-binding domains. PNAS 87 2112-2116. (doi:10.1073/pnas.87.6.2112)

Meyer C, Schneider B, Jakob S, Strehl S, Attarbaschi A, Schnittger S, Schoch C, Jansen MW, van Dongen JJ, den Boer ML et al. 2006 The MLL recombinome of acute leukemias. Leukemia 20 777-784. (doi:10.1038/sj.leu.2404150)

Mishra BP, Ansari KI \& Mandal SS 2009 Dynamic association of MLL1, H3K4 trimethylation with chromatin and Hox gene expression during the cell cycle. FEBS Journal 276 1629-1640. (doi:10.1111/j. $1742-4658.2009 .06895 . x)$ 
Mo R, Rao SM \& Zhu YJ 2006 Identification of the MLL2 complex as a coactivator for estrogen receptor alpha. Journal of Biological Chemistry 281 15714-15720. (doi:10.1074/jbc.M513245200)

Monks DA, Arciszewska G \& Watson NV 2001 Estrogen-inducible progesterone receptors in the rat lumbar spinal cord: regulation by ovarian steroids and fluctuation across the estrous cycle. Hormones and Behavior 40 490-496. (doi:10.1006/hbeh.2001.1717)

Nilsson S \& Gustafsson JA 2002 Estrogen receptor action. Critical Reviews in Eukaryotic Gene Expression 12 237-257. (doi:10.1615/ CritRevEukaryotGeneExpr.v12.i4.10)

Nilsson S, Makela S, Treuter E, Tujague M, Thomsen J, Andersson G, Enmark E, Pettersson K, Warner M \& Gustafsson JA 2001 Mechanisms of estrogen action. Physiological Reviews 81 1535-1565. van Oostveen J, Bijl J, Raaphorst F, Walboomers J \& Meijer C 1999 The role of homeobox genes in normal hematopoiesis and hematological malignancies. Leukemia 13 1675-1690. (doi:10.1038/sj.leu. 2401562)

Sims RJ III \& Reinberg D 2006 Histone H3 Lys 4 methylation: caught in a bind? Genes and Development 20 2779-2786. (doi:10.1101/gad. 1468206)

So CW \& Cleary ML 2004 Dimerization: a versatile switch for oncogenesis. Blood 104 919-922. (doi:10.1182/blood-2004-03-0992)

Strauss JF III, Martinez F \& Kiriakidou M 1996 Placental steroid hormone synthesis: unique features and unanswered questions. Biology of Reproduction 54 303-311. (doi:10.1095/biolreprod54.2.303)

Takeda S, Chen DY, Westergard TD, Fisher JK, Rubens JA, Sasagawa S, Kan JT, Korsmeyer SJ, Cheng EH \& Hsieh JJ 2006 Proteolysis of MLL family proteins is essential for taspase1-orchestrated cell cycle progression. Genes and Development 20 2397-2409. (doi:10.1101/ gad.1449406)

Taylor HS 2008 Endocrine disruptors affect developmental programming of HOX gene expression. Fertility and Sterility 89 e57-e58. (doi:10.1016/j.fertnstert.2007.12.030)
Taylor HS, Arici A, Olive D \& Igarashi P 1998 HOXA10 is expressed in response to sex steroids at the time of implantation in the human endometrium. Journal of Clinical Investigation 101 1379-1384. (doi:10.1172/JCI1597)

Trievel RC \& Shilatifard A 2009 WDR5, a complexed protein. Nature Structural E Molecular Biology 16 678-680. (doi:10.1038/ nsmb0709-678)

Wadsack C, Hrzenjak A, Hammer A, Hirschmugl B, Levak-Frank S, Desoye G, Sattler W \& Malle E 2003 Trophoblast-like human choriocarcinoma cells serve as a suitable in vitro model for selective cholesteryl ester uptake from high density lipoproteins. European Journal of Biochemistry 270 451-462. (doi:10.1046/j.1432-1033.2003. 03394.x)

Yau C \& Benz CC 2008 Genes responsive to both oxidant stress and loss of estrogen receptor function identify a poor prognosis group of estrogen receptor positive primary breast cancers. Breast Cancer Research 10 R61. (doi:10.1186/bcr2120)

Yokoyama A, Wang Z, Wysocka J, Sanyal M, Aufiero DJ, Kitabayashi I, Herr W \& Cleary ML 2004 Leukemia proto-oncoprotein MLL forms a SET1-like histone methyltransferase complex with menin to regulate Hox gene expression. Molecular and Cellular Biology 24 5639-5649. (doi:10.1128/MCB.24.13.5639-5649.2004)

Zhai Y, Kuick R, Nan B, Ota I, Weiss SJ, Trimble CL, Fearon ER \& Cho KR 2007 Gene expression analysis of preinvasive and invasive cervical squamous cell carcinomas identifies HOXC10 as a key mediator of invasion. Cancer Research 67 10163-10172. (doi:10. 1158/0008-5472.CAN-07-2056)

Received in final form 21 October 2011 Accepted 30 November 2011 Made available online as an Accepted Preprint 5 December 2011 